\title{
PII S0271-5198(96)00001-8
}

\author{
NINTH EUROPEAN CONFERENCE ON CLINICAL HEMORHEOLOGY \\ Siena, Italy, 28 June - 1 July 1995
}

\section{OPENING ADDRESS}

\section{9th EUROPEAN SYMPOSIUM ON CLINICAL HEMORHEOLOGY}

\author{
J-F STOLTZ \\ President of the European Society for Clinical Hemorheology \\ Past President, International Society of Biorheology \\ Hématologie (EA1728) - Faculté de médecine - BP 184 - 54500 Vandoeuvre les Nancy - France
}

Ladies and Gentlemen, my Dear Colieagues, Dear Tuilio,

It is a great pleasure and honour for me to open the 9th EUROPEAN SYMPOSIUM ON CLINICAL HEMORHEOLOGY on behalf of the European Society for Clinical Hemorheology (ESCH), today in Siena. For the second time, our meeting is being held in the prestigious surroudings or this beautiful city, under the Chairmanship of my friend Tullio DI PERRI. On behalf of all of us, let him be thanked for taking on that task at a time when clinical hemorheology is going through a difficult patch. I would like to include Simone in our acknowledgements, his charming wife who, among other responsibilities, was in charge of organizing the programme for accompanying peoples.

Since the first symposium held in Nancy in 1979, and until the 7 th symposium an European Coordination Committee (ECCCH) composed of nominated representatives from all. groups or national societies were in charge of the: perenniality of our meetings, and every two yearsplanned the organisation and the venue of the next Conference. The creation, two years ago in Vienna, of an International Society, without any prior consultation of the European coordinating Committee and European Societies, created a schism. This is a fact, and I have always regretted the loss of the motives that presided over the creation of the $\mathrm{ECCCH}$. To preserve our assets and pursue the cycle of european Conferences, the federation of European groups or societies for clinical hemorheology was created, which now gathers 15 societies and more than 1,200 members. This federation shall continue the missions of the ECCCH. It was therefore decided at a meeting of the European board in Bologna, in November of 1994, to confirm Lisbon as the venue for the 10th symposium, under the chairmanship of my friend Professor MARTINS $E$ SILVA. I have no doubt that until then current wonds will have healed. 
I believe however that the time for dispute has passed, and that concerted action is needed for the development of hemorheology, and that synergy between willing people will permit proper development of our discipline.

Different hypothesis are possible One proposal in my recent open letter, is to create, together with national and continental societiesconcerned with CLINICAL HEMORHEOLOGY (Europe, Japan, China, India, North and South America), and perhaps by restructuring the current international society, an international federation. But we must have a serious reflexion because this solution can create problems for the INTERNATIONAL SOCIETY OF BIORHEOLOGY (ISB) and we must keep in mind that ISB was first named in REYKJAVICK in 1966 ISH (International Society of Hemorheology), before A.L. COPLEY, A. SILBERBERG and others tried to broaden the society, partly by changing its name during the second International Congress in Heidelberg in 1968. For these reasons a second hypothesis proposed to me in recent letter by Giles Cokelet, President elect of ISB; is possible. IIt is that the H ISCH becomes a part within the ISB and that the ISCH stays, a continental society in continuation of the defunct ECCCHJthink that this solution, which permet a stengthening of allpart of Biorheology, seems to me a good proposal.

In the course of this Conference, the FAHRAEUS MEDAL will be awarded to its 8 th recipient, my friend A. EHRLY, to whom I express my sincere congratulations. I also want to express our thanks to HOESCHST FRANCE LABORATOIRES for their sustained interest in our meetings since 1979.

The stage is set, the actors are in place, all is ready to make this Conference a great scientific success. But another way I hope that you will find time to profit from this historical city and that you will attend the traditional and colourful Palio fiesta.

Siena, June 28th, 1995 